\title{
PERIPATUS (MACROPERIPATUS) GEAYI IN PANAMA
}

\author{
By Charles T. Brues \\ Biological Laboratories, Harvard University
}

As the Caribbean islands and adjacent mainland have been more carefully explored by zoologists interested in terrestrial invertebrates, information on the distribution of Onychophora in this area has slowly accumulated. A quite considerable number of species are now known to occur there, but as these animals are by no means abundant, the geographical range of the several species is poorly known.

I have recently received from Dr. Ralph Buchsbaum a specimen from El Cermano, near the west coast of Panama, north of Panama City. It is one of a series of five obtained for him by a friend of Mr. James Zetek. Dr. Buchsbaum had them under observation and they served him as subjects for some remarkably fine colored motion pictures as well as for black and white photographs.

This species is Macroperipatus geayi described by Bouvier in his "Monographie des Onychophores" in 1907 from the coast of Guiana. It was later reported from Panama by Clark $^{1}$ on the basis of a specimen from La Chorrera. The present writer recorded it from the Santa Marta Mountains, Colombia ${ }^{2}$ on the basis of two collections.

As the color of all the Neotropical species fades rapidly in alcohol, Bouvier was unable to ascertain the color of M. geayi in life, and noted no conspicuous pattern. Clark mentions "a broad, transverse, obscure yellow band" just behind the head. The specimens seen by me from Colombia also possessed the pale band or "necktie," with one exception. In the living ones observed by Dr. Buchsbaum the band is cream colored, but soon fades to nearly white in alcohol. The

1Smithsonian Misc. Coll., vol. 60, no. 17, p. 2 (1913).

2Psyche, vol. 32, p. 160 (1925). 
general body color is red brown or rust colored. Morphologically it seems certain that there are no specific differences between the type and the gaudily marked Panamanian specimens. Dorsally the body bears lozenge-shaped marks, very distinct in contracted individuals, but much less noticeable when the body is extended. A similar conspicuous band is present in at least two other Caribbean forms, Macroperipatus torquatus Von Kennel and Peripatus manni Brues, as well as in the Andean Oroperipatus peruvianus Brues.

\section{A Note Concerning Aggregations of \\ Ululodes villosa BEAUvoIS.}

On June 15th, 1940, I was collecting dragonflies along the little Jicomé river in the lower valley of the Yaque del Norte in Santo Domingo. While wading in the streambed below the highway bridge ( $\mathrm{Km}$. 214, Monte Christi road), and crowding my way between some bushes that overhung a riffle at a narrows, I disturbed a company of these big brown Ascalaphids. A chance stroke of my net against the bushes flushed several dozen of them. They fluttered, butterfly-like, around my head for a few minutes, and then settled again on twigs overhanging the water.

Later, in the mountains near San Jose de las Matas I flushed another colony from the pendant low-hanging bough of a large tree where it overhung the riffle in the Iguamo river. These also fluttered about wildly for a time, and then reassembled on the same boughs, quite disappearing from view in the process.

JAMES G. NEEDHAM. 

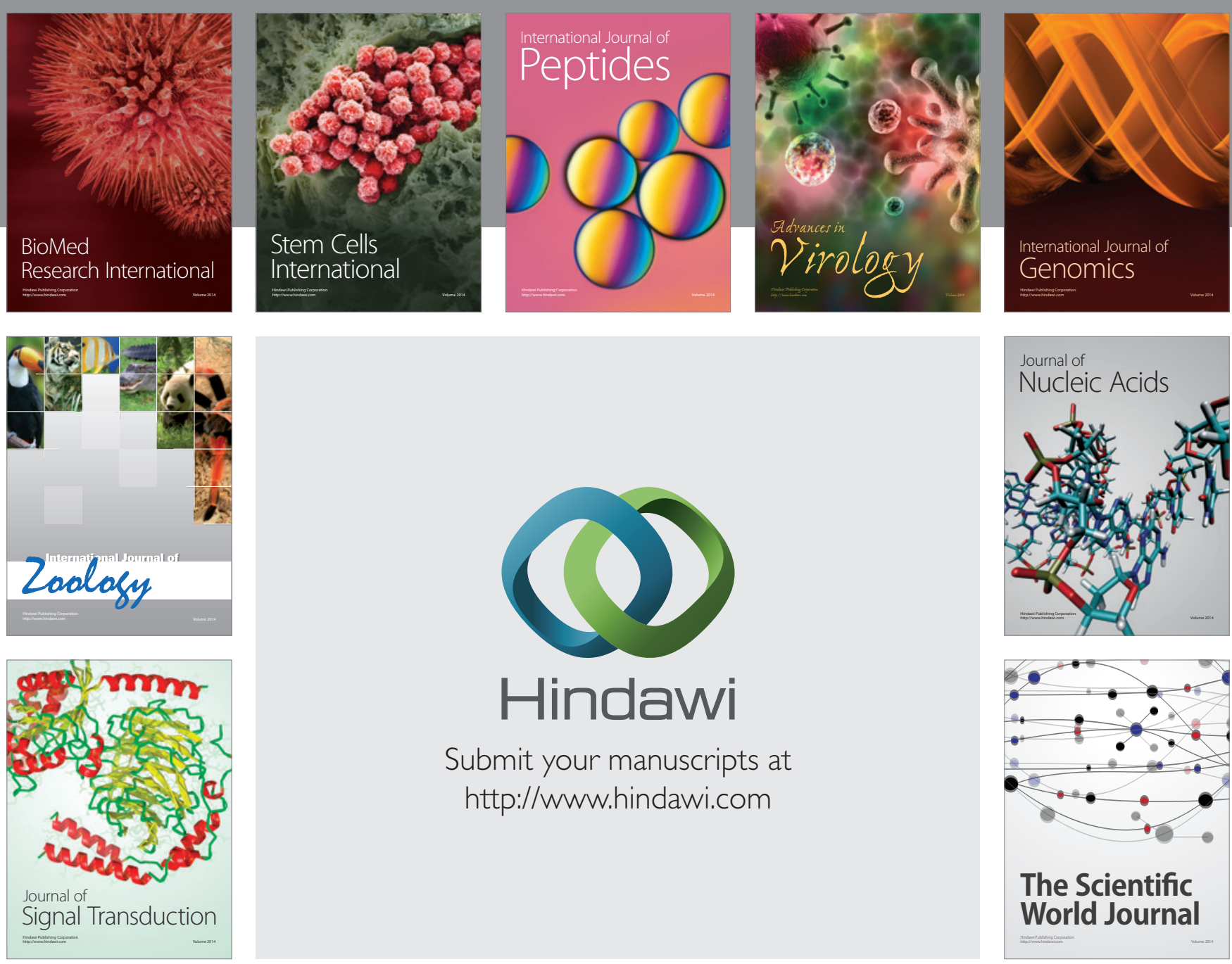

Submit your manuscripts at

http://www.hindawi.com
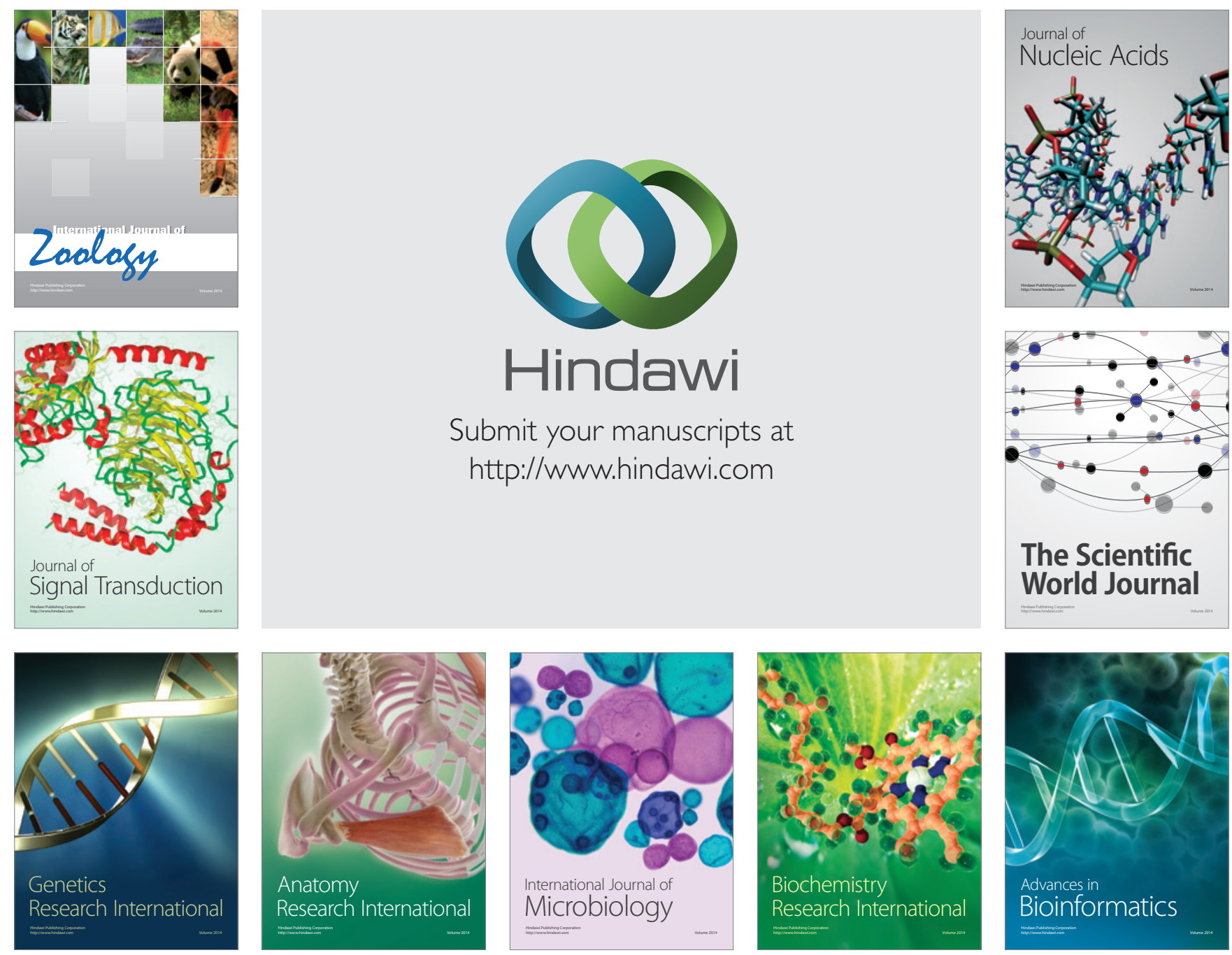

The Scientific World Journal
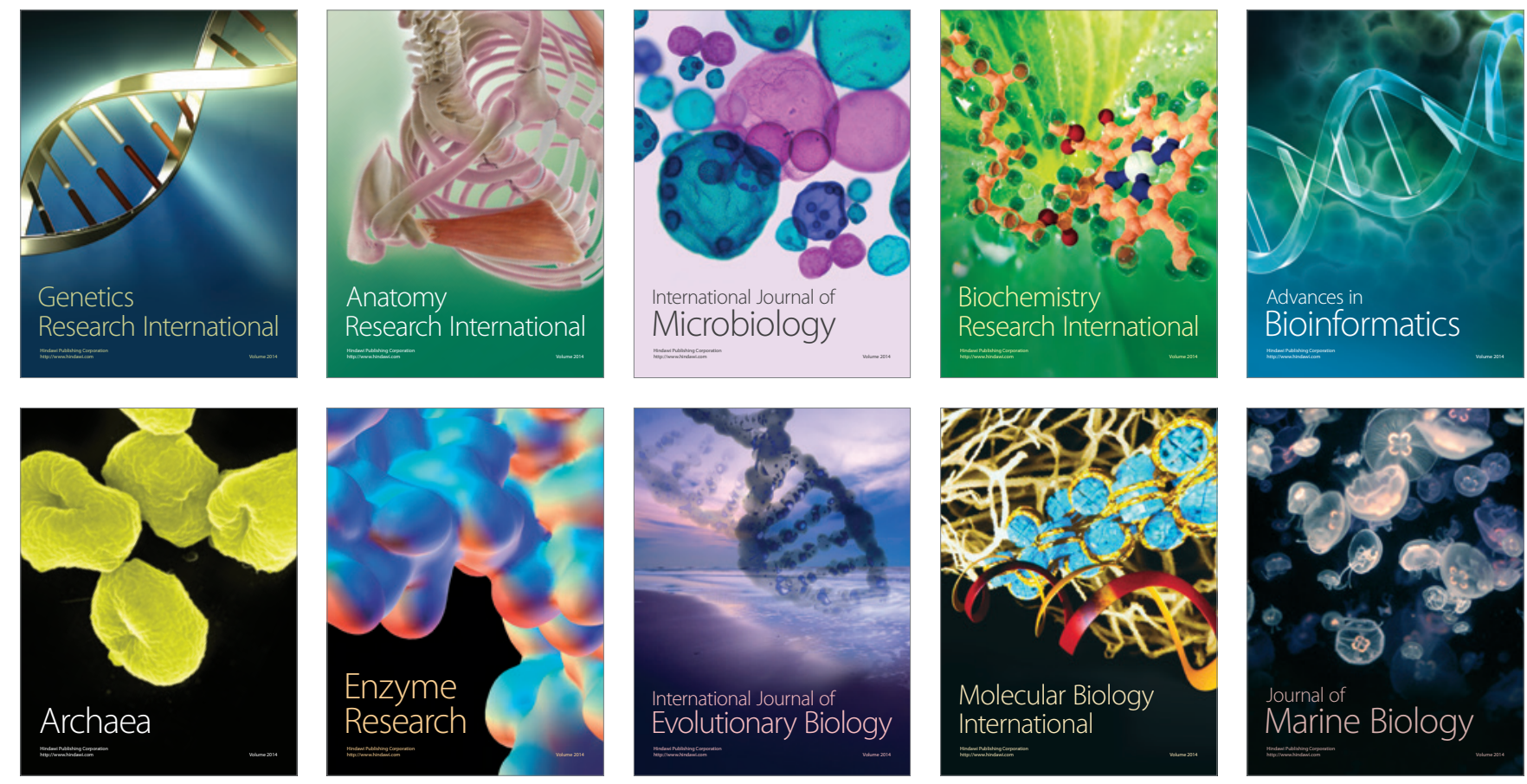